\title{
Identification of proteins in sensitive and tolerant lines of sunflower (Helianthus annus L.) under water deficit
}

\author{
Babak MAGHSOUDI DAMAVANDI ${ }^{1,2}$, Shahram LAK ${ }^{1}$ Mehdi GHAFFARI $^{2,3}$, Mojtaba ALAVIFAZEL ${ }^{4}$, \\ Tayeb SAKINEJHAD ${ }^{5}$
}

Received February 05, 2020; accepted March 11, 2021. Delo je prispelo 5. februarja 2020, sprejeto 11. marca 2021.

\begin{abstract}
Identification of proteins in sensitive and tolerant lines of sunflower (Helianthus annus L.) under water deficit

Abstract: The importance of examining environmental stresses and their role in predicting and evaluating the growth and yield of crops is very evident. Environmental stresses are the most important factor in reducing agricultural yields worldwide. In order to evaluate the environmental impact of water loss on the amount of proteins affected in sunflower, an experiment was conducted in randomized complete block design with three replications at Karaj Oil Seeds Research Institute. In order to study the response of susceptible line (BGK221) and tolerant line (RGK46) under drought stress conditions, extraction of protein by acetone deposition method was performed in 8 leaves and of 3 seedlings in each replication. The amount of extracted protein was determined by Bradford method using two-dimensional electrophoresis and existence of significant difference between the bands in sensitive and tolerant lines was investigated. A total of 467 repeatable bands were found in the tolerant line and 417 repeatable bands appeared in the sensitive line. Among these proteins, 6 bands in tolerant line (No $503,1901,904,3301,7011,9005)$ and 6 bands in sensitive line (No 704, 811, 3205, 4108, 7307, and 9207) were significantly affected by drought stress. In both sensitive and tolerate lines the main consequence is increase in amount of protein. The results showed that the most important factor of tolerant line adaptive for environmental stress conditions is maintaining normal cell metabolism, keeping moisture in the cell, strengthening cellular structure and antioxidant defense. The study also showed that drought stress had the greatest effect on cytoplasmic and nucleus proteins, metabolism and energy of proteins.
\end{abstract}

Key words: sunflower; environmental stress; twodimensional electrophoresis; proteomics.
Določanje beljakovin v občutljivih in toleratnih linijah sončnic (Helianthus annus L.) v razmerah pomanjkanja vode

Izvleček: Pomen preučevanja okoljskih stresov in njihove vloge v napovedovanju in vrednotenju rasti in pridelka gojenih rastlin je samoumevno. Okoljski stresi so v svetovnem merilu najpomembnejši dejavniki, ki zmanjšujejo pridelke kmetijskih rastlin. $\mathrm{Z}$ namenom ovrednotenja vpliva pomanjkanja vode na količino beljakovin v sončnicah je bil izveden popolni naključni bločni poskus s tremi ponovitvami na Inštitutu za preučevanje oljnih semen, Karaj, Iran. Za preučevanje odziva na sušni stres občutljive (BGK221) in tolerantne linije (RGK46) sončnic so bili narejeni izvlečki beljakovin iz osmih listov treh sejank v vsaki ponovitvi $\mathrm{z}$ acetonsko depozicijsko metodo. Količina beljakovin $\mathrm{v}$ vsakem izvlečku je bila določena $\mathrm{z}$ bradfordovo metodo $\mathrm{z}$ dvo dimenzionalno elektroforezo, kjer so bile preučevane značilne razlike med progami občutljivih in tolerantnih linij. Celokupno je bilo v tolerantnih linijah ugotovljenih 467 ponovljivih prog in 417 ponovljivih prog v občutljivih linijah. Med temi beljakovinami je bilo v tolerantni liniji 6 prog (No $503,1901,904,3301,7011,9005)$ in v občutljivi liniji 6 prog (No 704, 811, 3205, 4108, 7307, 9207), na katere je značilno vplival sušni stres. $\mathrm{V}$ obeh linijah je bila značilna posledica sušnega stresa povečanje količine beljakovin. Rezultati so pokazali, da so pri tolerantni liniji najpomembnejši mehanizmi prilagoditve na okoljski stres vzdrževanje normalne celične presnove, ohranjanje vsebnosti vode v celicah, ojačevanje celičnih struktur in antioksidacijska obramba. Raziskava je pokazala, da ima sušni stres največji učinek na beljakovine citoplazme in jedra in na presnovo beljakovin.

Ključnebesede: sončnica; okoljski stres; dvodimenzionalna elektroforeza; proteomika

Department of Agronomy, Ahvaz Branch, Islamic Azad University, Ahvaz, Iran.

2 Department of Agronomy, Khuzestan Science and Research Branch, Islamic Azad University, Ahvaz, Iran.

3 Seed and plant Improvement Institute, Agricultural Research, Education and Extension Organization (AREEO), Karaj, Iran.

4 Department of Agronomy, Ahvaz Branch, Islamic Azad University, Ahvaz, Iran.

5 Department of Agronomy, Ahvaz Branch, Islamic Azad University, Ahvaz, Iran. 


\section{INTRODUCTION}

Plants need the presence of nutrients in the soil, protection against pests and diseases, and the presence of appropriate environmental factors to grow well and maintain their health (Maghsoudi, 2006). The increasing world attention to the production of food to eliminate hunger and restore the food needs of the large consumer community has led to a massive effort across the world in the fields of establishment of wastelands, increasing the cultivating area, and increasing the efficiency of agricultural units, parallel with developing agricultural mechanization and soil fertility, evolving irrigation systems, combating pests and plant diseases, breeding and producing resistant seeds. Water is one of the most common and, at the same time, one of the most important compounds on the planet. The variation and abundance of plants in different parts of the earth depends on the amount of water available for the plants more than any other environmental factor. Drought tolerance is a complex feature that is affected by various plant and environmental variables. Identification of factors causing drought tolerance at the molecular level can be effective in the preparation of tolerant cultivars. Drought is one of the environmental stresses that causes harmful effects on most of the stages of plant growth, organ structure and their activities (Fulda et al., 2011, Passioura, 2007, Ishfaq et al., 2009). The response of plants to environmental stresses is different in morphological, anatomical, cellular and molecular levels (Dinakar et al., 2012). The ability of plants to adapt to environmental stresses depends on the type, intensity and duration of stress, plant species, and the stage of occurrence of stress (Passioura, 2007; Asl et al., 2003). Proteomics is referred as the analysis of a collection of proteins encoded by the genome (Karam et al., 2007). This technology provides quantitative and qualitative analysis of a large number of proteins; unlike the genome, which is a constant and unchanging nature, the proteome is fundamentally dynamic and variable, the proteome differs from organism to organism according to the type of tissue, cell, organ and environmental conditions (Goksoy et al., 2004). The study of the proteome of the intracellular organs may provide valuable information about the role of the protein. Several proteomics studies have been performed on proteome patterns of the organelles such as nucleus (Lawlor et al., 2002), chloroplasts (Ferro et al., 2003), mitochondria and plasma membranes (Adebayo et al., 2012). Sunflower is one of the important oily plants in the world and also Iran is in an arid and semiarid region, the preparation and identification of tolerant cultivars can help increase yield and develop its cultivation area.

\section{MATERIALS AND METHODS}

This research was carried out at the research farm of Seed and Plant Improvement and Production Institute located in the Mard Abad Road, Karaj. In this study, sensitive line (BGK221) and drought tolerant line (RGK46) were identified. For this purpose, sunflower inbred lines were cultivated in two separate experiments under normal irrigation and drought stress conditions in a randomized complete block design with three replications. The experimental plots had $3 \times 3$ meter Dimensions and included 3 planting lines, lenght of 2 meters (on agricultural land). The distance between the rows was $60 \mathrm{~cm}$ and the distance between the plants in each row was 25 $\mathrm{cm}$. Normal irrigation was from 10 to 14 days and water stress was carried out through irrigation when irrigation was terminated in 2-8 leaf stages. Samples were randomly selected from 5 plants per plot and transferred were taken to a laboratory for protein identification. The quantity of extracted protein was determined by Bradford method (Bradford, 1976). Proteome pattern was obtained in two lines and in two aforementioned conditions using two dimensional electrophoresis. In the first dimension the proteins were separated by isoelectric focusing method based on isoelectric point and using IPG, and in the second dimension, the proteins were separated based on molecular weights using SDS-PAGE. After staining with Coomassie Brilliant Blue solution and scanning the gels, the difference between the appeared bands was investigated using PD Quest version 6 software-test.-The data of protein quantity and a significant difference between the bands in sensitive and tolerant lines was investigated. Significant differences between bandsof sensitive and tolerant lines were investigated by $\mathrm{t}$-test.

\section{RESULTS AND DISCUSSION}

When plants are exposed to environmental stress, they respond to stress at the plant, cell, or molecule level. The pattern of production of many proteins changes in response to plant water depletion (Hajheidari et al., 2007). Plants to counteract or reduce the effects of drought stress may change the pattern of gene response or the amount of proteins within the tissue (Kanlaya et al., 2005). 


\subsection{CHANGE OF SENSITIVE LINE (BGK221) PROTEINS UNDER STRESS}

Under stress conditions in sensitive line, 6 protein bands were investigated from 12 detected bands. Aforementioned bands have increased in expression (Fig. 1a,). Araus et al. (2002) in the effects of non-living stresses on the protein content of two wheat cultivars (sensitive and tolerant) in the seedling stage, has concluded that in drought stress, the root proteins in sensitive cultivar I increased significantly. These observations largely matched with the results of researchers who studied the changes in the protein content of wheat root and endosperm in the early stages of budding under dehydration stresses and reported that response to stress is specific to tissue conditions (Bakalova et al., 2008).

\subsection{ENOLASE}

Band No. 704 was identified as an enolase cytopla-

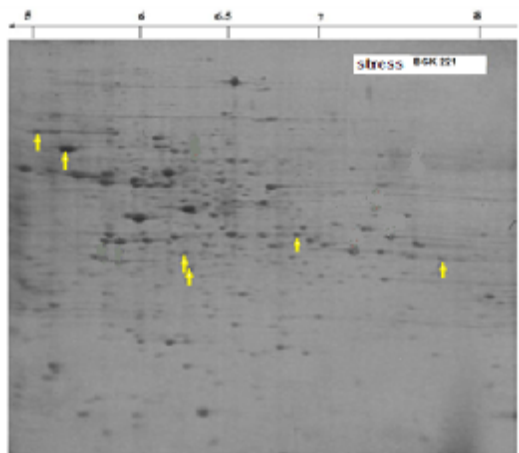

smic form in the sensitive line, in which its expression was increased by 2.3 times in stress conditions. This increase reflects the ability of this line to produce this enzyme to supply energy and continue its vital processes. Increase of enolase due to drought stress in corn (Riccardi et al., 1998) and Arabidopsis (Wei et al., 2011) has been reported. Hajduch et al. (2007) has reported increase in the level of this enzyme in the sunflower oil line (Hajduch et al., 2007). Proteins such as enolase and 6 phosphoglycerate kinase play a vital role in controlling the key pathways of energy metabolism, such as glycolysis.

\subsection{PHOSPHOGLYCERATE MUTASE INDEPEND- ENT OF 2-3 BISPHOSPHOGLYCIRATE}

The cytoplasmic form of this protein (811) was identified in the sensitive line and its expression increased by 25.5 times under stress conditions. Gulcin (2012) has reported the increase in expression of this protein in soybeans under stress. This enzyme is the catalyzer of

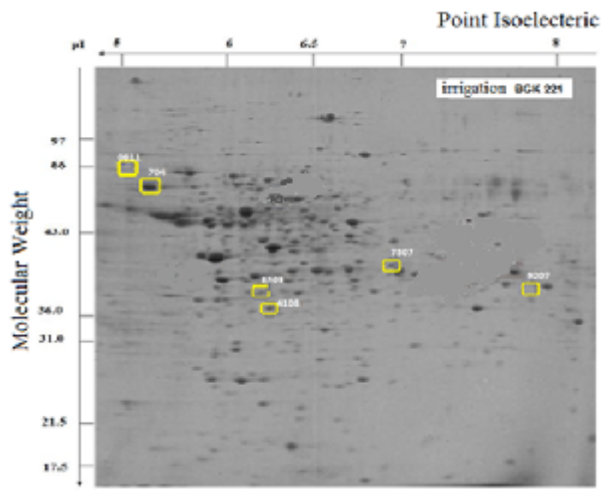

Figure 1a: Proteome pattern of sunflower sensitive line in irrigation and stress

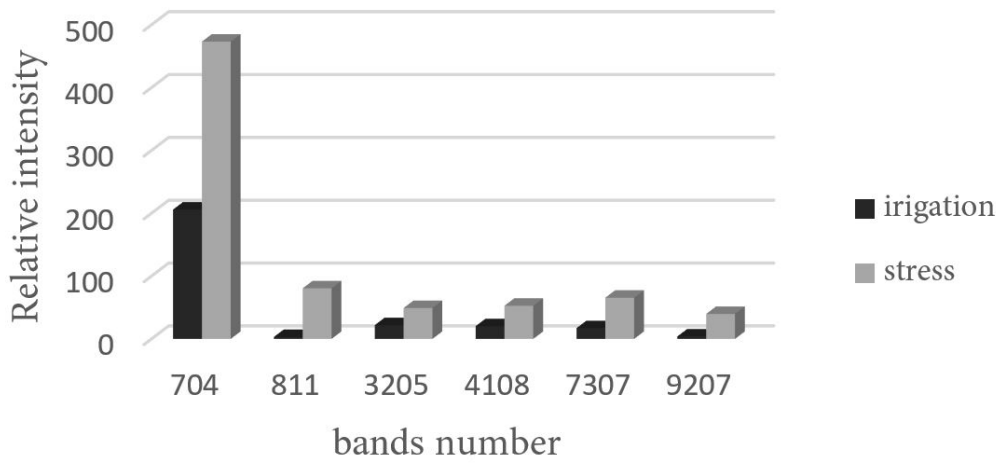

Figure 1b: Change of proteins on the sensitive line 
the reversible catalytic conversion of 3-phosphoglycerate to 2-phosphoglycerate in the presence of magnesium ion, in process of glycolysis. According to Hajduch et al. (2007), this enzyme contributes to the balance between 3-phosphoglycerate and 2-phosphoglycerate (Hajduch et al., 2007). Increasing the level of this enzyme in sensitive line could be due to this regulatory role.

\subsection{AUXIN CAUSED BY PROTEIN}

The band number 4108 belongs to this enzyme, which its expression in cell nucleus has increased 2.6 times. The role of this protein is unknown.

\subsection{MALATE DEHYDROGENASE}

The cytoplasmic form of this protein was detected in the sensitive line (3205) and its expression increased by 2.2 times in stress conditions. Malate dehydrogenase is an important enzyme of cellular metabolism and catalyzes the two-way conversion of oxaloacetate, and malate (Musrati et al., 1998). This enzyme increases its activity under drought stress in plants to provide high energy requirements (Guicherd et al., 1997). Increased activity of this enzyme was observed in bread wheat (Wang et al., 2008) and Arabidopsis (Ndimba et al., 2005). Pereira et al. (2016) conducted a research on proteomic analysis of barley sensitive and tolerant genotype under drought stress. They have reported the increase of this enzyme in the barley tolerant genotype that shows the role of this enzyme in drought tolerance (Pereira et al., 2016), while the level of this enzyme declined in the sensitive line (Nezami et al., 2008).

\subsection{CHALCONE SYNTHASE}

The cytoplasmic form of this protein stain was detected in the sensitive line (7307), which was increased 3.8 times. Chalcone synthase (CHS) is a key enzyme in the pathway of biosynthesis of flavonoids, and its expression is one of the determining factors in the pathway of anthocyanins biosynthesis. CHS typically occurs in different plant species under various types of stress such as UV, injuries, and microbial pathogens and drought condition, resulting in the production of compounds with various activities such as antimicrobial activity (phytoalexins), insecticidal activity and antioxidant activity or suppressing direct or indirect UV light (Dao et al., 2011). CHS is a key enzyme in the flavonoid biosynthesis pathway. Increased chalcone synthase levels can play a role in antioxidant defense under stress.

\subsection{GLYCERALDEHYDE TRIPHOSPHATE DEHY- DROGENASE}

The cytoplasmic form of glyceraldehyde triphosphate dehydrogenase (band 9207) was detected, which has 10.1 times higher expression. Considering the significant increase in the level of phosphoglycerate mutase enzyme, the increased activity of glycine aldehyde triphosphate dehydrogenase enzyme in this line was expected in line with the continuation of the glycolysis cycle. Increased glyceraldehyde 3-phosphate dehydrogenase can play role in plant tolerance under stress conditions by contribution in providing energy and antioxidative defense. (Table1).

\subsection{CHANGE OF TOLERATING LINE (RGK46) PROTEINS UNDER STRESS}

Under stress conditions, 6 protein bands were investigated from 18 detected bands. In tolerating line, the band No. 904 showed the highest percentage in increase expression (Fig2a).

\subsection{SIMILAR TO DIHYDROFLAVONOL REDUC- TASE}

This protein was detected in the cytoplasm in the tolerant line with band No. 503. Its expression increased 2.3 times in stress conditions. Ghaffari et al (2013) in the study of the effect of drought stress in sunflower, reported a doubling of this protein in both sensitive and tolerant lines (Ghaffari et al 2013). This protein is involved in the pathway of biosynthesis of anthocyanin, which is part of the secondary metabolite biosynthesis (Dinakar et al 2012). Increasing the expression of this enzyme in this line, which is one of natural molecular antioxidants, is in line indicates its protective role and compatibility with drought stress. Anthocyanin has a protective role against various environmental stresses. 


\subsection{LINOLEATE 9S-LIPOXYGENASE}

In the tolerant line, the cytoplasmic form of this protein band was identified with the number 1901 and its expression increased by 2.3 times in stress conditions. Ghaffari et al. (2013) reported the reduction of this pro- tein in both sensitive and tolerant lines in the study of the effect of drought stress (Ghaffari et al., 2013). This protein is involved in the oxylipin biosynthesis pathway, which is part of the lipid metabolism. Lipoxygenase is involved in plant resistance to environmental stress. Its function involves oxidoreductase activity.

Table 1: Properties of expressed proteins in the sensitive line (BGK221)

\begin{tabular}{|c|c|c|c|c|c|c|c|c|c|}
\hline SSP & Protein & $\begin{array}{l}\text { Registration } \\
\text { number }\end{array}$ & Bands & $\begin{array}{l}\text { Percentage } \\
\text { overlap }\end{array}$ & Irrigation & Stress & $\begin{array}{l}\text { Protein } \\
\text { ratio }\end{array}$ & Protein role & $\begin{array}{l}\text { Protein } \\
\text { location }\end{array}$ \\
\hline 704 & Enolase & NP_001105896.1 & 149 & 17 & 205.9 & 473.2 & 2.30 & Energy & Cytoplasm \\
\hline 811 & $\begin{array}{l}\text { Phosphoglycerate } \\
\text { mutase,2,3- } \\
\text { bisphosphoglycerate- } \\
\text { independent }\end{array}$ & NP_187471.1 & 122 & 14 & 3.167 & 80.6 & 25.45 & Energy & Cytoplasm \\
\hline 3205 & $\begin{array}{l}\text { Malate dehydrogenase, } \\
\text { cytoplasmic }\end{array}$ & O48905.1 & 179 & 15 & 21.97 & 49.2 & 2.24 & Metabolism & Cytoplasm \\
\hline 4108 & Auxin-induced protein & AAB84222.1v & 107 & 8 & 20.33 & 52.8 & 2.6 & Unknown & nucleus \\
\hline 7307 & Chalcone synthase & Q9ZU06 & 278 & 19 & 17.13 & 65.6 & 3.83 & Metabolism & Cytoplasm \\
\hline 9207 & $\begin{array}{l}\text { Glyceraldehyde } \\
\text { 3-phosphate } \\
\text { dehydrogenase }\end{array}$ & AES72079.1 & 240 & 30 & 3.933 & 39.8 & 10.12 & Energy & Cytoplasm \\
\hline
\end{tabular}
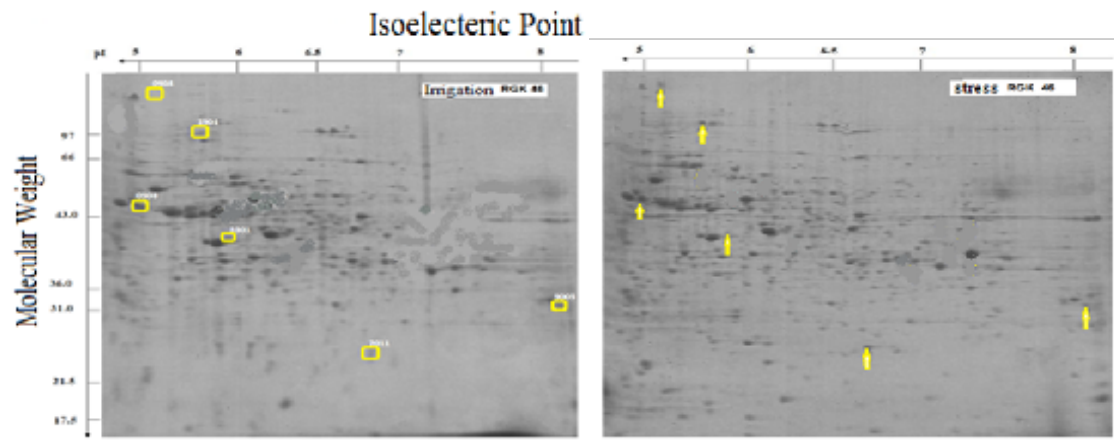

Figure 2a: Proteome pattern of sunflower tolerant line in irrigation and stress

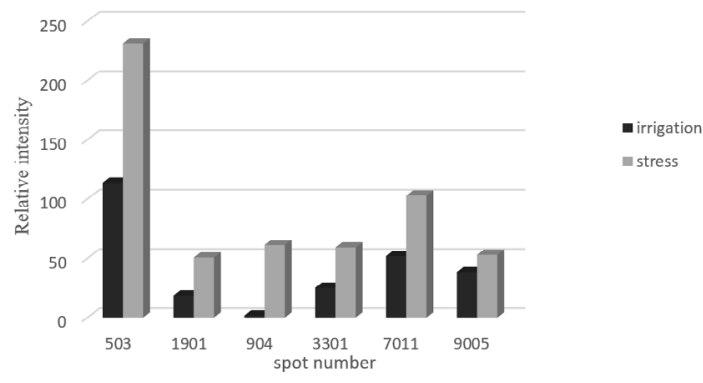

Figure 2: Change of proteins on the tolerance line 


\subsection{UBIQUITIN CARBOXYL- TERMINAL HYDRO- LYZE}

In the tolerant line, the cytoplasmic form of this protein band was identified with the number 904 and its expression increased by 36.7 times in stress conditions. This enzyme has the activity of cysteine type peptidase (a catalyst for hydrolysis of peptide bands in the polypeptide chain by the mechanism in which the remained sulfhydryl group in the active center acts as a nucleophile) and hydrolase of ubiquitin (catalysis for hydrolysis of thiol depending on an ester, thioester, amide, peptide or iso-peptide chain formed by the C-terminus of glycineubiquitin). (Ubiquitin Proteasome System) is almost entirely involved in the regulation of all stages of growth in plants and is likely to play a major role in many hormonal pathways and cellular vital responses (Dreher and Callis, 2006).

\subsection{POLYMYXIN BIFUNCTIONAL RESISTANCE PROTEIN}

The aforementioned protein, was identified in cell cytoplasm with band number 3301 and its expression increased by 3.2 times in stress conditions. Ghaffari et al. (2013) reported the increase in expression of this protein in the tolerant line and its reduction in sensitive lines (Ghaffari et al., 2013) while investigating the effect of drought stress on sunflower. Its molecular function involves the coupling of coenzyme and oxidoreductase activity (catalysis of oxidation-reduction reactions in which a $\mathrm{CH}-\mathrm{OH}$ group acts as a hydrogen or electron donor and reducer of $\mathrm{NAD}^{+}$and $\mathrm{NADP}^{+}$) and transferase activity relating to hydroxymethyl- and hydroxyformyl. Increasing the level of this enzyme in the tolerant line could indicate its defensive role in removing free radicals and adapting to drought stress in the plant.

\subsection{GLYCERALDEHYDE 3-PHOSPHATE DEHY- DROGENASE}

In the tolerant line, the cytoplasmic form of glyceraldehyde 3-phosphate dehydrogenase (band No. 7011) was identified which shows its relation to glycolysis and energy. Increasing the level of this protein is a quick response to supply the needed energy in drought stress condition through glycolysis and oxidative defense. Ferro et al. (2003) reported the increase in levels of this enzyme in response to stress in Arabidopsis Thaliana (Ferro et al. 2003). Caruso et al. (2009) reported an increase in this protein in tolerant line of peanut under drought stress condition (Caruso et al., 2009). Balbuena et al. (2011) also reported the distinct expression of this protein in sunflower in conditions of cold stress (Balbuena et al., 2011).

\subsection{BAND NO. 9005}

Based on the standard protein comparison model, the type of the above band was not detected in tolerant line. Also, the location of the protein and its role are unclear, but increased by 1.38 times in stress conditions. (Table2)

\subsection{RELATIVE CHANGES IN PROTEINS}

According to the research (Ghaffari et al., 2013) and among the sensitive and tolerant sunflower lines, it can be identified BGK221 as a sensitive line and the line RGK46 as a tolerant line (Maghsoudi et al., 2020). A total of 467 repeatable bands were found on the tolerant line and 417 repeatable bands appeared on the sensitive line. Among these proteins, 6 bands in tolerant and sensitive lines were significantly affected by drought stress. Among these proteins, 6 bands in tolerant line were similar to dihydroflavonol reductase (503), seed linoleate 9S-lipoxygenase (1901), ubiquitin carboxyl-terminal hydrolas (904), bifunctional polymyxin resistance protein ArnA-like (3301), glyceraldehyde-3-phosphate dehydrogenase (7011), unknown (9005)\} and 6 bands in sensitive line (enolase (704), phosphoglycerate mutase,2,3-bisphosphoglycerate-independent (811), malate dehydrogenase, cytoplasmic (3205), auxin-induced protein (4108), chalcone synthase (7307), glyceraldehyde 3-phosphate dehydrogenase (9207) were significantly affected by drought stress; in both sensitive and tolerate lines the main consequence is increase in amount of protein. (Fig 3, Fig 4) 
Table 2: Properties of expressed proteins in the tolerance line (RGK46)

\begin{tabular}{|c|c|c|c|c|c|c|c|c|c|}
\hline SSP & Protein & $\begin{array}{l}\text { Registration } \\
\text { number }\end{array}$ & Bands & $\begin{array}{l}\text { Percentage } \\
\text { overlap }\end{array}$ & Irrigation & Stress & $\begin{array}{l}\text { Protein } \\
\text { ratio }\end{array}$ & Protein role & $\begin{array}{l}\text { Protein } \\
\text { location }\end{array}$ \\
\hline 503 & Similar to & AAK68820.1 & 103 & 11 & 113.7 & 230.9 & 2.03 & metabolism & Cytoplasm \\
\hline 904 & $\begin{array}{l}\text { Ubiquitin } \\
\text { carboxyl- } \\
\text { terminal } \\
\text { hydrolase }\end{array}$ & XP_002524120.1 & 112 & 5 & 1.67 & 61.17 & 36.63 & metabolism & Cytoplasm \\
\hline 1901 & $\begin{array}{l}\text { Seed linoleate } \\
\text { 9S-lipoxygenase }\end{array}$ & P24095.1 & 123 & 19 & 24.10 & 76.23 & 3.16 & metabolism & Cytoplasm \\
\hline 3301 & $\begin{array}{l}\text { Bifunctional } \\
\text { polymyxin } \\
\text { resistance protein }\end{array}$ & XP_003538161.1 & 101 & 14 & 25.17 & 59.07 & 2.35 & $\begin{array}{l}\text { Disease } \\
\text { Defense }\end{array}$ & Cytoplasm \\
\hline 7011 & $\begin{array}{c}\text { Glyceraldehyde- } \\
\text { 3-phosphate } \\
\text { dehydrogenase }\end{array}$ & AEP71393.1 & 252 & 36 & 51.80 & 102.77 & 1.98 & Energy & Cytoplasm \\
\hline 9005 & Unknown & Unknown & - & - & 38.40 & 52.87 & 1.38 & Unknown & Unknown \\
\hline
\end{tabular}

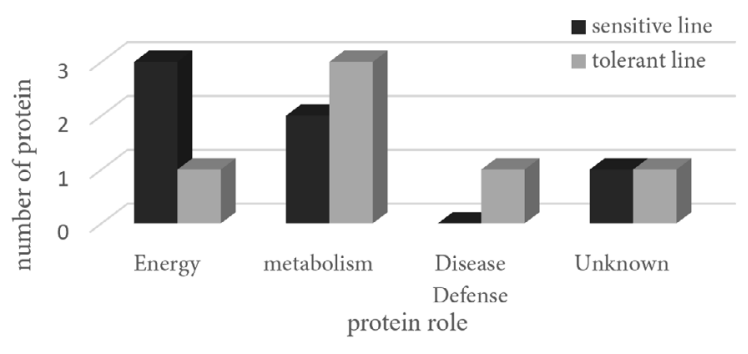

Figure 3: Protein classification by role

\section{CONCLUSION}

Given that water stresses have significant negative impacts; it is necessary to control these tensions to create a sustainable environment. Plants are very effective in protecting the environment. To prevent the extinction of plant species and the lack of water resources in the environment, it should be noted that the plant's characteristics and abilities are in the context of environmental stress. In this study, the classification of proteins based on the energy, metabolism, and defense function (Fig 3, Fig 4) showed that proteins had increased in sensitive and tolerant line. Research of protein in sensitive line and tolerant line, showed that the most important factors of tolerant line adaptive for environmental stress conditions are: maintaining normal cell metabolism, keeping moisture, strengthening cellular structure and antioxidant defense. The study also showed that water stress had the greatest effect on cytoplasmic/ nucleus proteins and metabolism/ energy proteins. The sensitive line tries to compensate for the damage caused by stress by increasing energetic

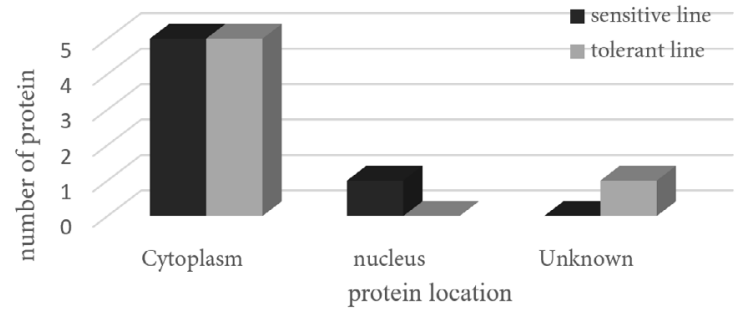

Figure 4: Protein classification by location

proteins. But the key to success in the tolerant line is increased lipid synthesis in the cell membrane and increased hydrophilic proteins in the face of stress.

\section{REFERENCE}

Adebayo, A.G., Akintoye, H.A., Aina, O.O., Olatunji, M.T., Shokalu, A.O. (2012). Assessment of organic amendments on growth and flower yield of sunflower (Helianthus annuus L.). Libyan Agricultural Research Centre Journal International, 3(1), 24-29.

Araus, J. L., Slafer, G. A., Reynolds, M. P., Royo, C. (2002). Plant breeding and drought in C3 cereals: What should we breed for? Annals of Botany, 89, 925-940. https://doi.org/10.1093/ aob/mcf049

Asl, K.K., Mazaheri, D., Peighambari, S. A. (2003). Effect of four irrigation intervals on the seed yield and quantitive characteristics of sunflower cultivars. Iranian Journal Agricultural Science, 34, 293-301.

Bakalova, S., Nedeva, D., Mckee, J. (2008). Protein profiles in 
wheat seedlings subjected to dehydration stress. Applied Ecology and Environmental Research, 6, 37-48. https://doi. org/10.15666/aeer/0602_037048

Balbuena, T. S., Salas, J J., Martínez-Force, E., Garcees, R., Thelen, J.J. (2011). Proteome analysis of cold acclimation in sunflower. Journal of Proteome Research, 10, 2330-2346. https://doi.org/10.1021/pr101137q

Bradford, M, M. (1976). A rapid and sensitive method for the quantitation of microgram quantities of protein utilizing the principle of protein-dye binding. Analitical Biochemistry, 72, 248-254. https://doi.org/10.1016/00032697(76)90527-3

Caruso, G., Cavaliere, C., Guarino, C., Gubbiotti, R., Foglia, P., Laganà, A. (2008). Identification of changesin Triticum durum L. leaf proteome in response to salt stress by two-dimensional electrophoresis andMALDI-TOF mass spectrometry. Analitical and Bioanalitical Chemistry, 391, 381-390. https://doi.org/10.1007/s00216-008-2008-x

Dao, T. T. H., Linthorst, H. J. M., Verpoorte, R. (2011). Chalcone synthase and its functions in plant resistance. Phytochemistry Reviews, 10, 397-412. https://doi.org/10.1007/ s11101-011-9211-7

Dinakar, C., Djilianov, D., Bartels, D. (2012). Photosynthesis in desiccation tolerant plants: energy metabolism and antioxidative stress defense. Plant Science, 182, 29-41. https://doi. org/10.1016/j.plantsci.2011.01.018

Dreher, K. \& CALLIS, J. (2006). Ubiquitin, hormones and biotic stress in plants. Section of Molecular and Cellular Biology, Plant Biology Graduate Group Program, University of California, Davis, One Shields Avenue, Davis, CA 95616, USA. Annals of Botany, 99, 787-822. https://doi.org/10.1093/aob/ mcl255

Ferro, M., Salvi, D., Brugiers, S., Miras, S., Kowalski, S., Louwagie, M. (2003). Proteomics of the chloroplast envelope membranes from Arabidopsis thaliana. Molecular and Cellular Proteomics, 2, 325-45. https://doi.org/10.1074/mcp. M300030-MCP200

Fulda, S., Mikkat, S., Stegmann, H., Horn, R. (2011). Physiology and proteomics of drought stress acclimation in sunflower (Helianthus annuus L.). Plant Biology, 13, 632-642. https:// doi.org/10.1111/j.1438-8677.2010.00426.x

Ghaffari, M., Toorchi, M., Valizadeh, M., Komatsu, S. (2013). Differential response of root proteome to drought stress in drought sensitive and tolerant sunflower inbred lines. Functional Plant Biology, 40(6), 609-617. https://doi. org/10.1071/FP12251

Goksoy, A. T., Demir, A. O., Turan Z. M., Dagustu N. (2004). Responses of sunflower (Helianthus annuus L.) to full and limited irrigation at different growth stages. Field Crop Research, 87, 167-178. https://doi.org/10.1016/j. fcr.2003.11.004

Guicherd, P., Peltier, JP., Gout, E., Bligny, R., Marigo, G. (1997). Osmoticadjustment in Fraxinus excelsior L. malate and mannitol accumulation in leaves under drought conditions. Trees, 11, 155-161. https://doi.org/10.1007/PL00009664

Gulcin, I. (2012). Antioxidant activity of food constituents: an overview. Archives of Toxicology, 86(3), 345-391. https://doi. org/10.1007/s00204-011-0774-2

Hajduch, M., Casteel, J. E., Tang, S., Hearne, L. B., Knapp, S.,
Thelen, J. J. (2007). Proteomic analysis of near-isogenic sunflower varieties differing in seed oil traits. Journal of Proteome Research, 6, 3232-3241. https://doi.org/10.1021/ pr070149a

Hajheidari, M., Abdollahian-Noghabi, M., Askari, H., Heidari, M., Sadeghian, S. Y., Ober, E. S., Hosseini Salekdeh, Gh. (2005). Proteome analysis of sugar beet leaves under drought stress. Proteomics, 5, 950-960. https://doi. org/10.1002/pmic.200401101

Ishfaq, M., Ali, A., Khaliq, A., Yaseen, M. (2009). Allometry Agronomic traits and yield of autumn planted sunflower hybrids under varing row spacing. Pakistan Journal of Biological Sciences, 46, 257-248.

Kanlaya, K. N., Sakda, D., Chaisiri, W., Sumontip, B., Manit, K., Piyada, T. (2005). Protein profiles in response to saltstress in leaf sheaths of rice seedlings. Science Asia, 31, 403-408. https://doi.org/10.2306/scienceasia1513-1874.2005.31.403

Karam, F., Lahoud, R., Masaad, R., Kabalan, R., Breidi, J., Chalita, C., Rouphael, Y. (2007). Evapotranspiration, seed yield and water use efficiency of drip irrigated sunflower under full and deficit irrigation conditions. Agricaltural Water management, 90, 213-223. https://doi.org/10.1016/j. agwat.2007.03.009

Lawlor, D. W. \& Cornic, G. (2002). Photosynthetic carbon assimilation and associated metabolism in relation to water deficits in higher plants. Plant Cell and Environment, 25, 275-294. https://doi.org/10.1046/j.0016-8025.2001.00814.x

Maghsoudi, B. (2006). MSc. thesis. Islamic Azad University, Tehran Science and Research.

Maghsoudi, B., Lak, Sh., Ghaffari, M., Alavifazel, M., Sakinezhad, T. (2020). Effect of agronomic traits and drought resistance indices on determination of susceptible and tolerant sunflower lines. Journal of Crop Production Research, 11(4), 2020.

Musrati, R. A., Kollarova, M., Mernik, N., Mikulasova, D. (1998). Malatedehydrogenase: distribution, function and properties. General Physiology and Biophysics, 17, 193-210.

Ndimba, B. K., Chivasa, S., Simon, W. J., Slabas, A. R. (2005). Identification of Arabidopsis salt and osmotic stress responsive proteins using two-dimensional difference gel electrophoresis and mass spectrometry. Proteomics, 5, 4185-4196. https://doi.org/10.1002/pmic.200401282

Nezami, A., Khazaei, H. R., Boroumand, R. Z., Null, N. (2008). Effects of drought stress and defoliation on sunflower. Desert, 12, 99-104.

Passioura, J.B. (2007). The drought environment: physical, biological and agricultural perspectives. Journal of Experimental Botany, 58(2), 113-117. https://doi.org/10.1093/jxb/ erl212

Pereira, S.I.A., Moreira, H., Argyars, K., Castro, P.M.L., Marques, A.P.G.C. (2016). Promotion of sunflower growth under saline water irrigation by the inoculation of beneficial microorganisms. Applied Soil Ecology, 105, 36-47. https://doi.org/10.1016/j.apsoil.2016.03.015

Rauf, S., Sadaqat, H. A., Khan, I. A., Ahmed, R. (2009). Genetic analysis of leaf hydraulics in sunflower (Helianthus annuus L.) under drought stress. Plant Soil and Environment, 55, 62-69. https://doi.org/10.17221/260-PSE

Riccardi, F., Gazeau, P., de Vienne, D., Zivy, M. (1998). Protein 
changes in response to progressive water deficit in maize. Plant Physiology, 117, 1253-1263. https://doi.org/10.1104/ pp.117.4.1253

Wei , Y. Z., Hu, F.C., Hu, G. B., Li, X. J., Huang, X. M., Wang, H. C. (2011). Differential expression of anthocyanin biosynthetic genes inrelation toanthocyanin accumulation in the pericarp of Litchi chinensis Sonn. PLoS ONE 6, e19455. https://doi.org/10.1371/journal.pone.0019455 